\author{
Abstracta Iranica \\ Abstracta Iranica Revue bibliographique pour le domaine irano-aryen \\ Volume 37-38-39 | 2018 \\ Comptes rendus des publications de 2014-2016
}

\title{
Mikhail Yu Treister. «A Hoard of Silver Rhyta of the Achaemenid Circle from Erebuni »
}

\section{Rémy Boucharlat}

\section{(2) OpenEdition}

\section{Journals}

Édition électronique

URL : http://journals.openedition.org/abstractairanica/45746

DOI : 10.4000/abstractairanica.45746

ISBN : 1961-960X

ISSN : 1961-960X

Éditeur :

CNRS (UMR 7528 Mondes iraniens et indiens), Éditions de l'IFRI

Référence électronique

Rémy Boucharlat, « Mikhail Yu Treister. «A Hoard of Silver Rhyta of the Achaemenid Circle from Erebuni » », Abstracta Iranica [En ligne], Volume 37-38-39 | 2018, document 66, mis en ligne le 30 décembre 2018, consulté le 27 septembre 2020. URL : http://journals.openedition.org/ abstractairanica/45746 ; DOI : https://doi.org/10.4000/abstractairanica.45746

Ce document a été généré automatiquement le 27 septembre 2020

Tous droits réservés 


\title{
Mikhail Yu Treister. « A Hoard of Silver Rhyta of the Achaemenid Circle from Erebuni »
}

\author{
Rémy Boucharlat
}

\section{RÉFÉRENCE}

Mikhail Yu Treister. «A Hoard of Silver Rhyta of the Achaemenid Circle from Erebuni », Ancient Civilizations from Scythia to Siberia, 21/1, 2015, p. 23-119

1 En 1968, au pied de la forteresse uratéenne d'Erebuni (dans la banlieue immédiate de Erevan) étaient découverts accidentellement dans une grande cruche trois rhyta et un gobelet en argent, ainsi qu'un autre objet qui a disparu peu après la découverte. Ces objets de luxe sont un protome de cheval monté d'un homme barbu, un protome de mouton dont la partie supérieure du vase porte une fresque de personnages. L'A. propose des comparaisons avec d'autres vases en métal, mais la datation de chacun d'eux-qui n'était peut-être la même pour ces objets qui ont été ensuite réunis- restent incertaines Pour l'enfouissement, l'A. propose la fin de l'époque achéménide, à l'image du trésor de Pasargades, ou même un peu plus tard, peut-être même pas avant le début du IIIe s. av.n.è. C'est une hypothèse. Suit un catalogue descriptif détaillé. RB. 


\section{AUTEURS}

RÉMY BOUCHARLAT

UMR 5133 CNRS-Université de Lyon 